\title{
HISTOLOGICAL AND ULTRASTRUCTURAL OBSERVATIONS ON GILLS OF TILAPIA NILOTICA L. (OREOCHROMIS NILOTICUS) IN LAKE QARUN, FAYOUM PROVINCE, EGYPT
}

\author{
Hoda M. Shoman' and Hanan S. Gaber ${ }^{2}$ \\ 1 - Zoology Department. Faculty of Science, Al-Azhar University for \\ Girls, Nasr City, Egypt. \\ 2- National Institute of Oceanography and Fisheries, Fish Research \\ Station, Egypt.
}

Key woed : histology. ultrastructura!. gills. Tilapia nilotica, Lake Qarun.

\section{ABSTRACT}

G ish productivity has been affected by a progressive increase of salinity and pollution in Lake Qarun. So. this work aimed to investigate the histology and ultrastructure of the gills of Tilapia nilotica to clarify the possible effect of water quality on the fish gills. The most observed changes include the occurrence of a prominent large number of chloride and mucous cells confined to gill filament. hyperplasia of primary lamellar epithelium which leads to obliteration of some interlamellar spaces between adjacent secondary gill lamellae, odema resulting in the separation of respiratory epithelium and inflammatory infiltration including eosinophils and macroplages. These findings demonstrate that Tilapia nilotica can adapt to poor conditions through cellular and histological changes.

\section{INTRODUCTION}

Lake Qarun is an inland water body in Fayoum province. Egypt. In the past. Lake Qarun was considered as reservoir of fresh water of the River Nile during the flooding season. Its salinity was always less than $1.0 \mathrm{gm} / \mathrm{L}$. Later. dams have 'geen constructed across the Nile stream where the water supply from the River Nile to this lake is being partially controlled and the water level in the lake started to decrease. With time, the salinity of the lake started to increase due to conveying dissolved salts into the lake and the excessive evaporation attained at the surface particularly during summer (Soliman, 1989). The average salinity of the lake increased gradually from $11 \mathrm{gm} / \mathrm{L}$ to about $81 \mathrm{gm} / \mathrm{L}$ in western side and $41 \mathrm{gm} / \mathrm{L}$ in the 
eastern side (Lucas, 1906; Soliman, 1989 and Hassan, 2002). Actually the salinity due to salt content ( $\mathrm{gm} / \mathrm{L}$ ) varies greatly in different areas of the lake, particularly near the outlets of the drains, where the lowest salinity can be observed, while the highest salinity often existed in the extreme western region (Soliman, 1989). Lake Qarun is bordered from its northern side by the desert, and by cultivated lands from its south and south eastern sides. The lake receives a continuous supply of drainage water which is loaded with salts, nutrients, wastes and pesticides (Abdel-Malek and Khalil, 1994). The annual increase of salinity in Lake Qarun and the decline of its fish production. were the subject of several investigators. Although, increasing of lake salinity, fresh water species, Tilapia zillii. Tilapia aurea and Oreochromis niloticus are the most existing fishes in the lake. The physiology of salinity tolerance in tilapia has been reviewed by Prunet and Bornancin, (1989).

The adaptive capacity to different salinities in teleosts depends on the integrated osmoregulatory function of numerous organs, mainly gills, digestive tract and kidney (Evans, 1984, Cataldi el al.,1988 and Cionie el al.,1991). The gills are the largest proportion of the outer surface area of fish, having few micrometers separating the blood from water (Wood and Sojvio, 1991), which facilitates gaseous exchange, but allows the branchial tissue to be exposed to variations of the medium. These induce morphological modifications or cellular adaptation related to the plasticity of the branchial epithelium (Laurent \& Perry, 1990).

The present study aims to clarify how $T$. nilotica could be adapted to poor water conditions. through histological and ultrastructural examination of the gills of this species.

\section{Fish:}

\section{MATERIAL AND METHODS}

Tilapia nilotica were collected from western and eastern stations in lake Qarun. Fish had an average length $14 \mathrm{~cm} . \pm 2$ and weight $54 \mathrm{gm} \pm 2$.

\section{Light microscopy:}

The freshly collected fish were immediately dissected and gill samples were fixed in Bouin's fluid for about 24 hrs. , then rinsed and dehydrated with a graded ethanol series, embedded in paraffin wax and sectioned at $5 \mu \mathrm{m}$ then stained with hematoxylin and eosin. The sections were examined and photographed on light microscope. 


\section{Transmission electron microscopy:-}

According to the method of Mercer and Birbeck (1966). gill samples were immediately fixed overnight at $4^{\circ} \mathrm{C}$ in $5 \%$ glutraldhyde in $0.1 \mathrm{M}$ sodium cacodylate buffer. After post fixation in $1 \%$ osmium tetroxide in the same cacodylate buffer for 2 hours, specimens were rinsed twice in the same buffer. delhydrated through a graded ethanol series and processed through propylene oxide into Epon 812. Sections were cut on ultra microtome, at first $1 \mu \mathrm{m}$ semi thin sections were stained with toluidine blue for light microscope. and then ultra thin sections were cut and picked up on mesh copper grids and stained with uranyl acetate. followed by lead acetate solution (Reymold. 1963). The ultra thin sections were examined by transmission electron microscope and electron micrographs were and photographed.

\section{Gill structure:}

\section{RESULTS}

Each gill arch of Tilapia nilotica bears a double row of primary gill filaments (non respiratory lamellae), and each filament carries two rows of secondary gill lamellae (respiratory lamellae). The gill filament lined by a thick stratified epithelium referred as primary epithelium. The epithelium contains several epithelial cell types; i.e. basal epithelial cells, mucous cells, mitochondria rich chloride cells and superficial pavement cells (Figs. $1 \& 2$ ).

The secondary gill lamella (respiratory lamella) is lined on both opposite sides by an epithelium that is two squamous cells layer thick. The external layer is characterized by the flat elongated pavement cells. Their external plasma membrane sometimes forms a system of microridges which give a fuzzy appearance. They flattened nuclei characterized by dense peripheral heterochromatin. The cells forming the innermost layer are joined together with fingerlike cytoplasmic projections.

Underlaying the epithelium, there is a layer of basal lamina which separates the epithelium from the major part of the pillar system. The pillar system is a collective term for the pillar cells and blood capillaries. The pillar cells are the main body of this system which supports the lamella. The pillar cell has a large nucleus occupies the greater part of the main cell body with irregular outline and heterochromatic clumps. The cytoplasm has few mitochondria and poor endoplasmic reticulum. Four cytoplasmic projections known as pillar arms, two arms on each side of the cell extend to overlap 
with the arms of the next pillar cell to form a space; (blood lacuna) in which blood cells move (Figs. $2 \& 11$ ).

Mucous cell:

Mucous cells are large modified columnar epithelial cells which synthesise, and secrete mucous, and may be stimulated by loca! irritation to release their entire mucigen contents. They are found at the surface between other epithelial cells of the primary gill epithelium and at the base of secondary gill lamellae (Fig.12). The mucous cells open to the external medium with a deep apical pit which is surrounded by extensions of adjacent pavement cells. Sparce microvilli forming the brush border are seen at the surface of the mucous cells. The base of the cell is occupied by a highly condensed basal nucleus. The cytoplasm adjacent to the nucleus is packed with rough endoplasmic reticulum (RER). Small vacuoles and few mitochondria are present. The distended apical cytoplasm contains a dense aggregation of mucigen granules packed into membrane bound secretory vesicles. The secretory vesicles are rounded and range widely in electron density. Due to the large number of vesicles, the nucleus is displaced to the basal margin of the cell. Small cytoplasmic processes from the mucous cells extend between adjacent epitheljal cells (Figs. 5, 6, 13\&14).

\section{Chloride cell:}

Chloride cells are large, polygonal. rounded, ovoid or columnar in shape, irregularly spaced and usually covered by superficial pavement cells. They are characterized by a rich population of mitochondria evenly distributed throughout the cytoplasm, which are variable in size and shape. The extensive smooth walled tubular membrane system ramifies throughout the cytoplasm. The cytoplasm contains also scattered ribosomes and glycogen particles. The euchromatic nucleus has a little heterochromatin. A conspicuous feature of many chloride cells is the presence of an apical pit opening to external environment. The pit is usually located between two superficial pavement cells. The pit may contain finely granulated material (Figs. 5, $7 \& 15$ ). The other chloride cells which were not in contact with the external medium had sheets of pavement cells covering their apical surfaces.

Eosinophil granular cells:

Eosinophils are phagocyte cells with a similar metabolism like neutrophils. The increased number of eosinophils in the tissue indicates some disorders. Eosinophils are characterized by large intensely basophilic granules of cytoplasm. The specific granules are 
membrane bounded of uniform size. Cells are not readily identified in routine histological sections, due to the water solubility of their densely basophilic granules which tend to be lost during preparation. When stained with the basic dye, toluidine blue, the granules bind to the dye changes in color to red, a phenomenon described as metachromasia (Fig. 5. 6\& 7). With electron microscopy, the large specific granules are membrane bounded. round or oval in shape and filled with closely packed electron dense material. The cytoplasm contains free ribosomes. glycogen particles. few mitochondria and fragmented rough endoplasmic reticulum (RER) scattered out of the cytoplasm (Fig. 17).

\section{Variation in gill structure:}

ish gill sections were examined and all alterations were recorded. The main marked change in fish specimens collected from the western region of the lake, where the highest salinity exists; is an odematous change. The swelling of the inter-cellular spaces between the epithelial lining and the basal lamina of the respiratory gill lamellae led to the appearance of wide spaces from the base towards the tip of the gill lamellae (Fig. 3).

Extensive proliferation for both well developed mucous and chloride cells was obvious. Some of chloride cells have a large apical surface and became in direct contact with the external medium (Figs. $3 \& 4)$.

An increase in the cellular layer of the primary epithelium led to partial fusion of some of the adjacent respiratory gill lamellae was also observed (Figs. 3 \& 4). In addition. infilteration of large number of eosinophilic granular cells into the intercellular tissue was evident (Figs. 5, 6, 7, \& 8).

Hyperplasia of the gill filament epithelium was the dominant change recorded in the gills collected from the eastern region of the lake, where high saline and polluted water. The increase in the cellular layers of the epithelium resulted in the obliteration of the interlamellar space between respiratory gill lamellae.

Hyperplasia was often accompanied by extensive proliferation of both mucous and chloride cells. Clusters of chloride cells were evident, some of them showing signs of degeneration. In addition inflammatory cells including lymphocytes and macrophages were widely accumulated (Figs. 9, $16 \& 19$ ). 


\section{DISCUSSION}

In the present study, a large number of chloride cells located in the gill filament epithelium was observed in fish specimens, collected from west and east sides of Lake Qarun. The increase in number of gill chloride cells is known to occur in euryhaline teleosts transferred to salt water (Avella et al. 1993). This is also in agreement with Assem \& Hanke (1983) and Dange (1985), where Oreochromis mossambicus may be acclimatized to $65 \%$ salinity.

Foskett et al. (1983) have suggested that the development of the ion transport mechanism in euryhaline teleosts involves activation and proliferation of immature chloride cells followed by differentiation of these cells. These cells may have a role in ion transport in both fresh and saltwater-adapted teleosts, there is evidence that chloride cells take up ions, particulay $\mathrm{Na}+\mathrm{Cl}^{-}$and $\mathrm{Ca}^{2}+$ (laurent and Dunel 1980 and Flik et al. 1984).

According to previous studies, chloride cells located in lamellae may be involved in ion regulation in freshwater trout (Perry \& Wood 1985; Avella et al., 1987), whereas the increased number of chloride cells in filament in sea water reflects teleost adaptation to elevated external salinity (Karnaky et al., 1976; Thomson \& Sargent, 1977; Laurent and Dunel, 1980) and may be responsible for salt extrusion in hypertonic medium (Keys and Wilmer, 1932). This interpretation was strongly supported by the studies performed on opercular epithelium of Fundulus and Sartherodon (Foskett et al. 1981).

Karnakey et al. (1976) and Forskett et al., (1981) reported that apical pit is often correlated with adaptation to high salinities. Many authors observed the apical pit in the chloride cells of some fresh water adapted fishes including tilapias (Fishelson, 1980 and Maina, 1990), guppies (Straus. 1963) and Fundulus sp. (Philpott \& Copeland, 1963). Furthernore apical pit has been described in fresh water and sea water adapted Rivulus marmoratus at all tested salinities (King et al., 1989).

Azab et al. (1999) studied the morphology and ultrastructure of the gifl epithelial cells of euryhaline cyprinodont fish, Aphainus dispar in normal sea water fishes and the variation during acclimation to both hypersaline and fresh water. In sea water and hypersaline adapted fishes, chloride cells were confined to gill filament. whereas in freshwater adapted fishes, these cells were observed with some secondary lamellar epithelium in addition to the gill filament. In hypersaline adapted fishes a large contact area of chloride cell apical 
membrane with the external medium was observed. Coleman et al. (1977) did not observe any difference in the number or distribution of chloride cells at different salinities, but the fish displayed apical pits and enlargement of chloride cells in sea water, suggesting salt excretion induced by saltwater adaptation.

During salinity challenge, an increase in the number of ridges on epithelial cells was observed in various Tilapia species (Fishelson, (1980). In the present study. microridges of the external epithelial layer lining the respiratory gill lamellae were observed. However, the physiological role of this specific change is still unclear. but according to Fishelson, the phenomenon is more pronounced in the more euryhaline species and may participate in osmoregulation.

Increased mucous cell production and enhanced mucous secretion, often in considerable amount. is considered to be the most distinctive feature of teleost epidermis (Harris \& Hunt. 1975: Sibbing \& Uribe, 1985). Increased mucous secretion under toxic conditions is known to bar the entry of toxicants into the fish, probably by interacting with toxic ions and then resulting in the formation of a film of coagulated mucus on the surface of the gill, or by providing a physical barrier for macromolecules. (Kumar and Pant, 1981). The proliferation and migration of the specialized mucous cells on to the interlamellar tissue between secondary gill lamellae appears to be a protective response to induced ionic disturbances at gill surface.

The present results are in agreement with Kantham \& Richards (1995), where histological changes in the gills of carp exposed to phosphate buffered dilution water induced an extensive mucous cell proliferation on the lamellar and filamental epithelia, an increased infiltration of eosinophilic granular cells into the gill tissues, a moderate epithelial hyperplasia and an increase in the chloride cell densities on the gill epithelia.

Gill hyperplasia has been regarded as a common sign of chronic toxicity caused by various chemical pollutants. In the present study, mild to moderate gill hyperplasia was noted in west regions specimens, while severe hyperplasia was evident in east station specimens. It has been suggested that such a hyperplastic reaction may increase the epithelial thickness so as to retard or prevent the entry of toxic ions into the blood stream or to compensate for osmotic imbalance (Laurent, 1984).

The infiltration of eosinophilic granular cells and other granular leucocytes cells into the gill epithelium had been described as an 
inflammatory reaction in carp by various workers (Hornich \& Tomanek 1983; Kovacs-Gayer 1984) in response to different chemical toxic substances. As suggested by Al-Hussaini (1949), these granuiar cells might have an antitoxic effect although the exact mechanism involved is unknown.

The swelling of respiratory gill lamellae and Jifting of their epithelial lining due to the subepithelial edema was a common and conspicuous change in the present study. The appearance of extended lamellar oedematous spaces seems to implicate a protective and osmoregulatory manifestation of the gills. Hughes and Wright (1970), Hughes and Gray (1972) and Hughes (1978) have described the intercellular spaces in the secondary lameilae as lymphoid spaces and as these spaces contained a variety of white blood cells, these authors suggested that they might perform a function analogous to alveolar macrophages, and that the circulating fluid may be important in the protective and osmoregulatory functions of the gills.

According to Azab el al., (1999) the gills from hypersaline adapted fresh water fishes showed swelling and fusion of the adjacent secondary lamellae, ballooning of the epithelial cells and separation of the epithelial layers of secondary lamellae by intercellular spaces.These intercellular spaces communicate with the corresponding intercellular spaces of filament epithelium. a feature that may be an Important implication in consideration of transbranchial fluid movement (Laurent \& Dunel,1980).

On the other hand, the swelling of the intercellular spaces and infiltration of leucocytes was parallel to those alterations seen by Skidmore and Tovell (1972) when fishes were exposed to pollutants.

The presence of an increased number of chloride cells in the gill tissue once again suggests an increased ionic activity at the gill surface caused by the prevailing water quality conditions. According to Laurent and Perry (1991) rapidly occurring changes in the morphometry of epithelial, mucous and chloride cells may be adaptive or pathological changes, depending on the nature of the ionic disturbance and the toxicant involved.

So, in the present study, it can be concluded that the histological and ultrastructure alterations in the gill of Tilapia nilorica indicate an accelerated adaptive response to the increasing salinity and poor conditions of lake Qarun water at present. 


\section{REFERENCES}

Abdel-Malek, S. A. and Khalil, M. T. (1994). Aquatic habitate diversity, 2-lake Qaroun. In "Biological diversity of Egypt "H.M. Bishai (Ed). UNEP \& EEAA (National Biodiversity Unit [CF/6/05-02-2205] $60 \mathrm{pp}$.

Al-Husaini, A. H. (1949). On the functional morphology of the alimentary tract of some fish in relation to differences in their habits: cytology and physiology'. Q. J. Mic Sci. 90:323-355.

Assem, H. and Hanke, W. (1983). The significance of the amino-acids during osomotic adjustment in teleost fish 1 . changes in the euryhaline, Sarotherodon mossambicus. Comp. Bioch. and Physiol. 74A: 531-536.

Avella, M. ; Behout J. and Bornancin M. (1993). Salinity tolerance of two tropical fishes, Oreochromis aureus and O. niloticus. LBiochemical and morphological changes in the gill peithelium I. Fish biol.. 12: 243-254.

Avella M. ; Masoni A. ; Bornancin M. and Mayergostan N. (1987). Gill morphology and sodium influx in the rainbow trout and (Salmogairdneri) acclimated to artificial freshwater environments. J. Exp. Zool., 241: 159-169.

Azab, A. M. ; Moustafa, M. A. and Ragaa E. (1999). Histological and uitrastructural changes in the gill of Aphanius dispar. (Ruppell, 1928) during acclimation to different salinities. I. union Arab Biol., Cairo 12:379-397.

Cataldi E. : Crosetti D. ; Conte. G. : D'oviio D. and Cataudella S. (1988). Morphological changes in the oesophageal epithelium during adaptation to salinties in Oreochromis mossambiczs. O. niloticus and their hybrid F. J. Fish. Biol., 32: 191-195.

- Cioni, C. ; DE Merich. D. ; Cataidi, E. and Cataudella, S. (1991). Fine structure of chloride cells in fresh water and sea wateradapted Orcochromis niloticus (Linnaeus) and $O$. mossambicus (peters) J. Fish . Biolog., 39: 197-209. 
- Coleman, R. ; Yaron, Z. and Ilan, Z. (1977). An ultrastructural study of the mitochondria rich 'chloride' cells from the gills of freshwater and sea water-adapted Tilapia atrea subjected to a pesticide. Journal of Fish Biology, /l: 589-594.

- Dange, A. D. (1985). Branchial sodium potassium ATPase activity during osmotic adjustments in 2 freshwater. euryhaline teleosts Sarotheroion mossambicus and orange chormid Etroplus maculatus. M. Biol. 87:101-107.

Evans, D. H. (1984). The roles of gill permeability and transport mechanisms in euryhalinity. In Hoqr. W. S. \& Randall. D. (eds.): Fish physiology. Vol. 1OB. Academic Press. New York, pp. 239-283.

Flike, G. ; Wendelaar Bonga, S. E. and Fenwick. (1984). $\mathrm{Ca}^{2}+$ dependent phosphatase and $\mathrm{Ca}^{2}+$ depentent ATPasee activities in plasma membranes of eel gill epitheliumII.Evidence for transport high-affinity $\mathrm{Ca}^{2}+$ ATPase. Comp. Biochem. Physiol., 79B: 9-16.

Fishelson, L. (1980). Scanning and transmission electron microscopy of aquamose gill-filament epithelium from fresh-and seawater -adapted Tilapict. Environmental Biology of fishes. $5: 161-265$.

Foskett, J. K. ; Logsdon, C. D. ; Turner, T. ; Machen, E. \& Bern, H. A. (1981). Differentiation of the chloride extrusion mechanism during seawater adaptation of a teleost fish, the cichlid, Sarotherodon mossambicus. J. of Exp. Biol., 934:209-224.

Foskett, J. K. ; Bern. H. A. ; Machen, T. E. and Conner, M. (1983). Chloride cells and the hormonal control of teleost fish osmoregulation. J. Exp. Biol., 106:255-281.

Hassan, A. M. (2002). Ecological and Biological studies on Zooplankton in Lake Qaroun, Egypt. Ph. D. Thesis Fac. Sci.. Al-Azhar Univ.. 350pp. 
Harris, J. E. and Hunt, H. (1975). The fine structur of the epidermis of two species of salmonid fish, the Atlantic salmon ( Salmo salar L.) and brown trout (Salmotrutta L.) II Mucous cells. Cell. Tiss. Res., I63: 535-543.

Hornich, M. and Tomanek J. (1983). Necrotic processes in carp gilltissue caused by changes in aquatic medium. Veterinarni Medicina, ( Praha) 28:621-632.

Hughes, G. M. and Wright, D. E. (1970). A comparative study of the ultrastrucure of the water-blcod pathway in the secondary lamellae of teleost and elasmobranch fishes-benthic forms. Zeitschrift fur Zellforshung und Mikroskopische Anatomic. $104: 478-493$.

Huges, G. M. and Gray, L. E. (1972). Dimensions and ultrastructure of toadfish gills. Biological Bulletin, 143:150-161.

Hughes, G. M. (1978). Morphology and morphometrics of fish gills. Atti della Societa Peloritana di Scienze Fische Matermatiche Naturali, 34:333-335.

Kantham, K. P. L. and Richards, R. H. (1995). Effect of buffer on the gill structure of common carp, cyprinus carbio L.. and rainbowtrout, Oncorhynchus mykiss (Walbaum). J. of Fish Diseases, 18:41 1-423.

Karnaky, K. J. ; Kinter, L. B. ; Kinter, W. B. and Stirling, C. E. (1976). Teleost chloride cell. Il-Autoradiographic localization of gill $\mathrm{Na} / \mathrm{K}$ ATPase in Killifish Fundulus hetroclitus adapted to low and high salinity environments. J. Cell Bio.. 70: 157-177.

Keys, A. \& Wilmer, E. N. (1932). 'Chloride secreting cell' in the gills of fishes with special reference to the common eel. I. of Physiol. (London) 76:368-378.

King, J. A. C. ; Abel. D. C. and Dibona, D. R. (1989). Effects of salinity on chloride cells of the euryhaline cyprinodontid fish, Rivulus marmoratus. Cell Tiss. Res., 257: 367-377. 
Kovacs-Gayer, E. (1984). Histopathological differnetial diagnosis of gill changes with special regard to gill necrosis. Symposia Biological Hungarica, 23:219-229.

Kumar, S. and Pant, S. C. (1981). Histopathologic effects of acutely toxic levels of copper and zinc on gills, liver and kidney of Puntius conchonius (Ham.) Indian J. Exp. Biol.. 19:191-194.

Laurent, P. \& Dunel. S. (1980). Morphology of gill epithelia in fish. American J. Physiol., 238: 147-159.

Laurent, P. (1984). Gill internal morphology In: Hoor W.S. and Randall, D. J. (eds.) Fish Physiology. Vol. 10a, pp: 73-183, Acadamic Press, New York.

Laurent, P. \& Perry, S. F. (1990). Effects of cortisol on gill chloride cell morphology and ionic uptake in the freshwater trout, Salmo grirdner, Cell Tiss. Res.. 259: 429-442.

Laurent, P. \& Perry, S. F. (1991). Environental effects on fish gill morphology. Physiol. Zool., 64:4-25.

Lucas, A (1906). The salinity of Birket El-Quaroun. Survey. Notes. L. pp. 10-15.

Maina, J. N. (1990). A study of the morphology of the gills of an extreme alkalinity and hyperosmotic adapted teleost Oreochromis alcalicus grahami (Boulenger) with particular emphasis on the ultrastructure of the chloride cells and their modification with water dilution. A SEM and TEM Study. J. Anat. Embryol.. 18: 83-98.

Mercer, E. N. and Birbeck, M. S. (1956). Electron microscopy. A land book for biologist, 2nd edition Oxford, Blance Well Scientific Publication.

Meslual, A. H. (1973). Water and a salt budget of Lake Qaroun, Fayoum, Egypt. Ph.D. Thesis, Alexandria Univ. 109 pp.

Morissens, P. ; Roche, R. P. and Aglinog, C. (1986). La pisciculture intensive enenclose dans les grandes lagunes du Sud-Est Benin. Bois et Forets des Tropiques, 213:51-70. 
Perry, S. F. and Wood, C. M. (1985). Kinetics of branchial calcium uptake in the rainbow trout: effects of acclimation to various :xternal calcium levels. J. Expt. Biol., 116: 411-434.

Philpott, C. W. and Copeland, D. E. (1963). Fine structur eof chloride cells from three species of Fundulus. J. Cell. Biol., I8: 389404.

Prunet, P. and Bornancin, M. (1989). Physiology of salinity tolerance in tilapia: an uptake on basic and applied aspects. Aquatic living Resourcs 2:91-97.

Reynolds, E. S. (1963). The use of lead citrate at high $\mathrm{pH}$ as an electron opaque stain in an electron microscopy. J. Cell. Biol., 17:209212.

Skidmore, J. F. and Tovell, P. W. A. (1972). Toxic effect of zinc sulfate on the gills of rainbow trout. Wat. Res., 6: 217-230.

Sibbing, F. A. \& Uribe, R. (1985). Regional specializations in the oropharyngeal wall and food processing, in the carp () Cyprinus carpio L.) Netherlands J. Zool.. 35:377-422.

Soliman, G. F. (1989). The hydrology of Lake Qaroun, Fayoum Province Egypt, Part. I.: Physical Environmental Conditions. Bull. Inst. OceanOrg. \& Fish., ARE, 15 (1): 75-92.

Straus, L. P. (1963). A study of the fine structure of the so-called chloride cell in the gill of the guppy, Lebistes reticulatus. J. Physiol. Zool., 38: 183-198.

Thomson, A. J. and Sargent, J. R. (1977). Changes in the levels of chloride cells and $\mathrm{Na}^{+} / \mathrm{K}+-$ dependant ATPase in the gills of yellow and silver eels adapting to seawater. J. of Exp. Zool., 200:33-40.

Wood, C. M. and Soivio, A. (1991). Environmental effect on gill functions: an introduction. Physiol. Zool., 64: 1-3. 


\section{LEGEND OF FIGURES}

Fig. (1): A light micrograph of sagital section in gill of Tilapiat nilorica specimens showing general gill structure. Each gill filament composed of primary (non-respiratory) gill lamellae ( $\uparrow$ ) carrying double rows of secondary (respiratory) gill lameliae $(\uparrow \uparrow)$ the secondary gill lamcllae are equally spaced separated from each other from the free side and connected by interlamellar tissue at the base. $(\mathrm{H}$. \& E. X 100$)$.

Fig. (2): A magnitied part of gill filament showing, multilayered filament epithelium (E) and bilayered secondary gill lamella (S). Each secondary gill lamella composed of central pillar system (P.S.). The space between pillar cells formed lacunat through which red blood cells flow. The basilamellar region formed of different epithelial cells in between Jay mucous cells $(M)$ and chloride cells (C.C.). (H. \& E. X 1000).

Fig. (3): A lightmicrograph of sagital section in gill (west Qarun Station) showing partial fusion some of secondary gill lamellae by prolfierated interlamellar epithelial cells $(\uparrow \uparrow)$ and swelling of others due to the subepithelial odema $(\uparrow)$ (H. \& E. X 100).

Fig. (4): A magnified part of gills showing partially fusion of adjacent secondary gill lamellae. Swelling of the lamellae, degeneration and desquamation of the epithelial layer covering secondary lamellae, deformed pillar system and aggregation of mucous cells packed with mucous granules. (H. \& E., X 400).

Fig. (5) A light micrograph of semithin section of gill showing bilayered secondary gill lamellar epithelium $(\uparrow)$, pillar system (P.S.) composed of pillar cells (P.C.) . blood lacunae filled with red blood cells (r.b.c) and primary gill lamella covered by multicellular epithelium. Notice, the large well developed mucous cells $(\mathrm{M})$ which have a darkly stained nucleus at the base and well developed mucigen granules (*). (Toluidine blue X 1000).

Fig. (6) A light micrograph of semithin section of gill (west Qarum station) showing bilayered secondary gill lamellar epithelium \& pillar system ( pillar ceils, red blood cells 
and blood lacuna). Notice, the vaculated space or the appearance of intercellular spaces (ICS) between pillar system and epithelial layer covering lamellae. Part of multicellular complex of gill filament epithelium which contains different epithelial cells. infiltrated eosinophilic cells (*) which characterized by large densly stained granules and mucous cells (M) which have densly stained basal nucleus and well developed mucigen particles. (Toluidine blue X 1000).

Fig.(7) A light micrograph of semithin section of gill filament ( west Qarun station) showing, apex of gill filament covered multicelfular epithelium. Notice, the rich mitochondria chloride cells (C.C.) and well developed mucous cells (M). The chloride cells are in direct contact with the external medium through their apical pits $(\uparrow)$. The marginal blood vessel (B.V.) contains red blood cells and leucocytes. (Toluidine blue X1000).

Fig. (8) A light micrograph of semithin section through gill filament (west Qarun station) showing apex of gill filament. Notice, the complex multicellular epithelium covering including different types of epithelial cells (E). and theuappearance of intercellular spaces (ICS). infittrated eosinophile celis. corregated borders ( $\downarrow \downarrow$ ) covered by microridges which give a fuzzy appearance surface. Expanded congested blood vessel (B.V) filled with red blood cells and different leucocytes. The wall lining of the blood vessel became thinner. (Toluidine blue $\times 1000$ ).

Fig. (9) A lightmicrograph of semithin section through gill filament ( east Qarun station) showing. proliferation of interlamellar epithelial cells causing fusion of adjacent secondary gill lamellae, some of chloride cells (C.C.) have signs of degeneration, congesting blood lacunae, and separation of pillar system from lamellar epithelium. (Toludine blue $X$ $1000)$.

Fig. (10) A light micrograph of semithin section through gill filament (east Qarun station) showing complex multicellular macrophage infiltration ( $\uparrow$ ). numerous well developed chloride cells (C-C). (Toludine blue X 1000).

Fig. (11) An electronmicrograph of a part of secondary gill lamella showing, the outer bilayered epithelium $(\downarrow)$, the flat 
elongated pavement cells have oval nuclei (N) characterized by dense periphral heterochromatin, the cytoplasmic matrix contains fragmented rough endoplasmic reticulum, mitochondria and ribosomes. Pillar system (P.S.) which composed of pillar cell (P.C.), the lateral cytoplsmic processes (C.P.) of each pillar cell stretch out to touch those of adjacent pillar cells forming blood lacunae (B.L.) through which red blood cells (r.b.c.) flow. (X 3000).

Fig. (12) An electronmicrograph of gill (west Qarun station) showing the basal region of the secondary gill lamellae. Notice the well developed mucous cell (M) and rich mitochondria chloride cells (C.C.). (X 1800).

Fig. (13) An electronmicrgraph of gill showing well developed mucous cell which open to the external medium with a deep apical pit $(\downarrow \downarrow)$ which surrounded by extension of pavement cells. The mucous cell have large highly condensed nucleus $(N)$ its cytoplasm is packed with a large number of electron dense mucigen vesicles (M.V.). (X 3600).

Fig. (14) An electronmicrograph showing a mucous cell (M). Notice the extensive rough endoplasmic reticulum (RER), small cytoplasmic processes $(\uparrow)$ from the mucous cell extend between adjacent epithe! ial cells (X 5400).

Fig. (15): An electronmicrograph of gill (west Qarun station) showing two of large chloride cells sharing in a wide apical pit $(\uparrow \uparrow)$. surrounded by superficial pavement cells. Notice, the numerous rounded and oval mitochondria (m) distributed throughout the cytoplasm, the extensive smooth walled tubular membrane system, free ribosomes, scattered particles of glycogen, the euchromatic nucleus with small masses of heterochromatin. (X 7500).

Fig. (16) An electronmicrograph of gill (east Qarun station) showing degenerated chloride cells (C.C.). Notice the disorganized mitochondria (m), reduction of both mitochondria and tubular system, nucleus (N) with more electron dense heterochromatin clumps and cytoplasmic vacuolated spaces (V). (X 7000).

Fig. (17) An electronmicrograph of gill (east Qarun station) showing eosinophile ranular cell. Notice the large electron dense material packed cytoplasmic granules which have uniform size and membrane-bound, free ribosomes and fewrough. endoplasmic reticulum scatteredall over the cytoplasm. ( $X$ 5000). 

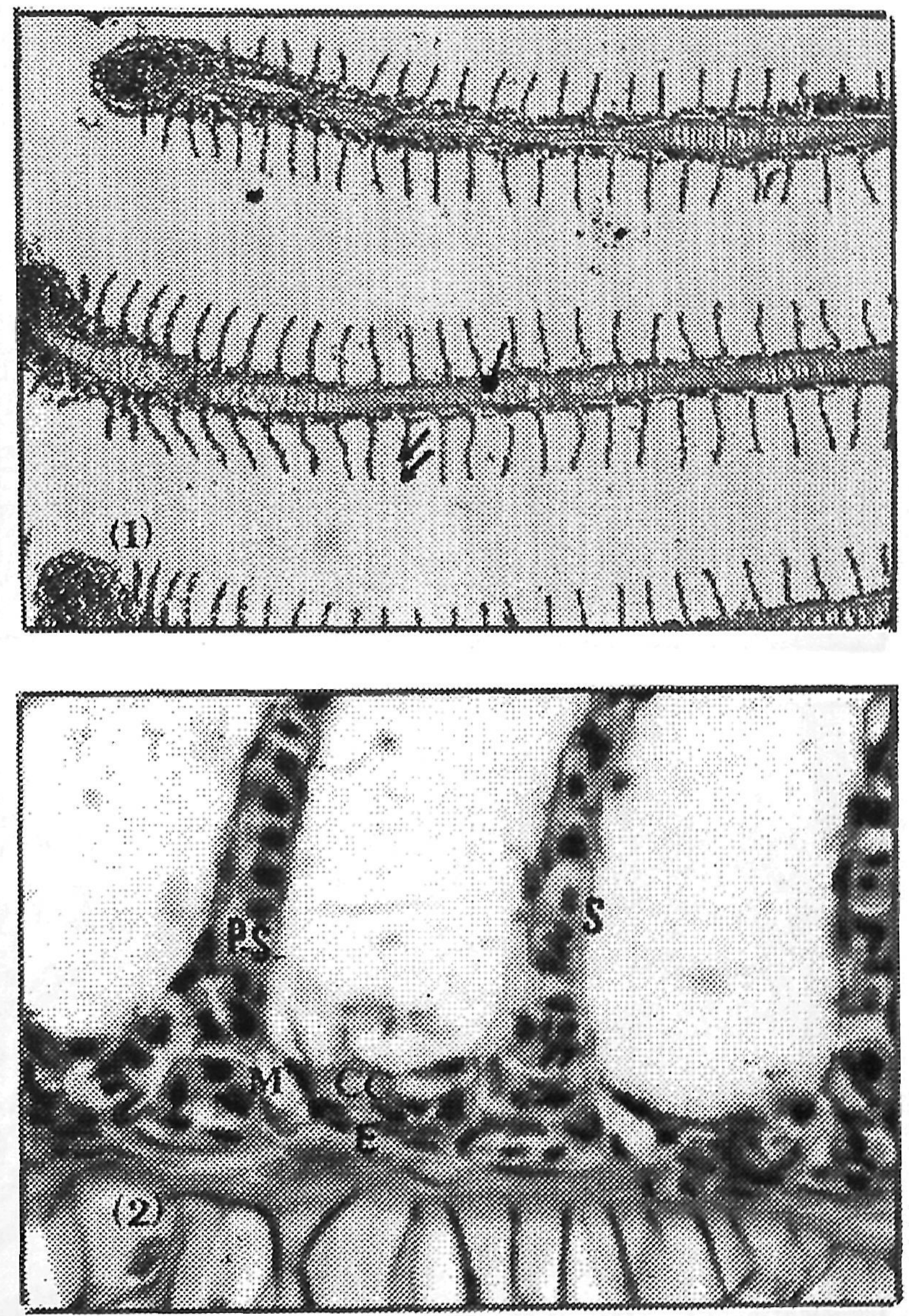

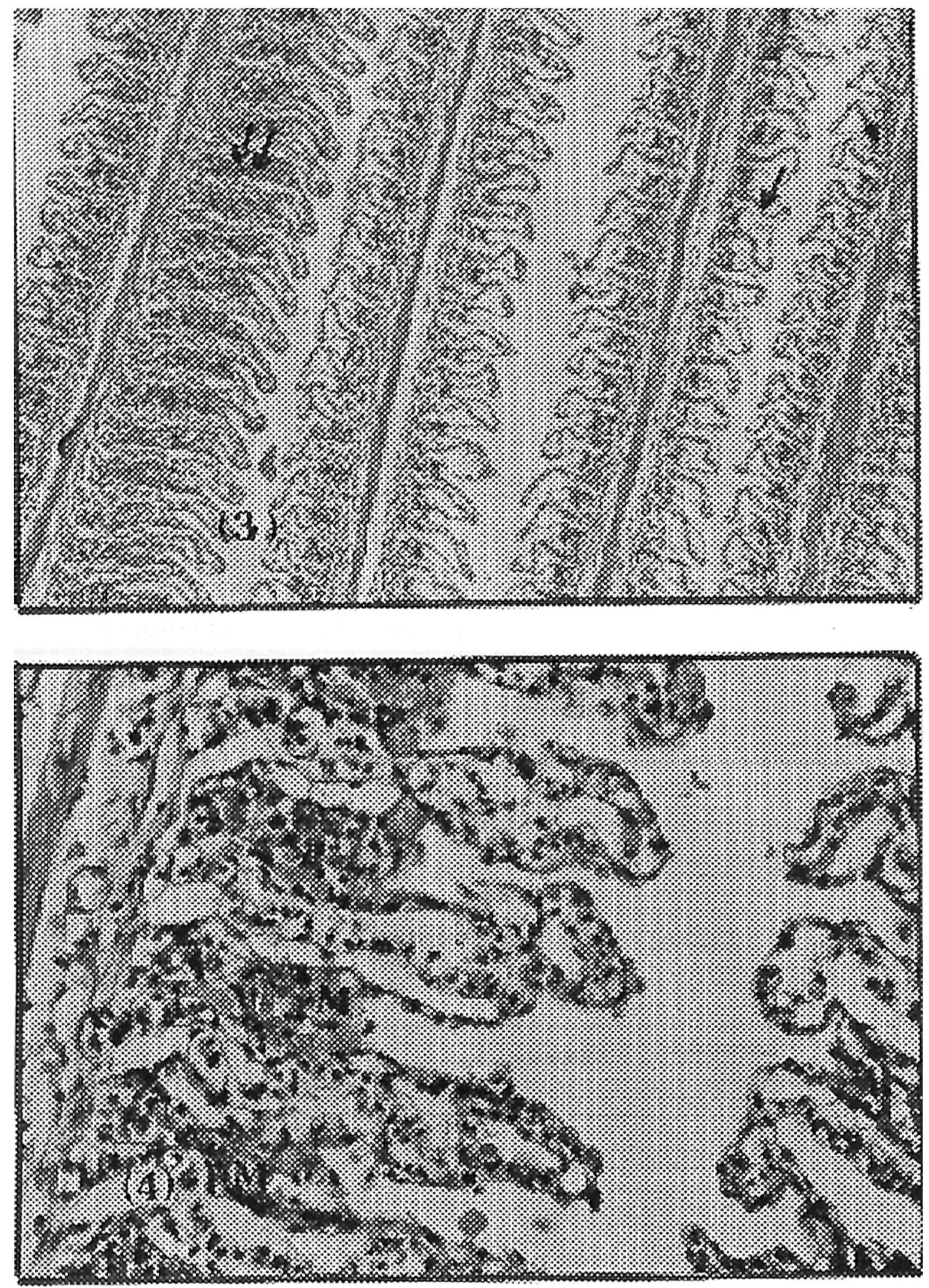

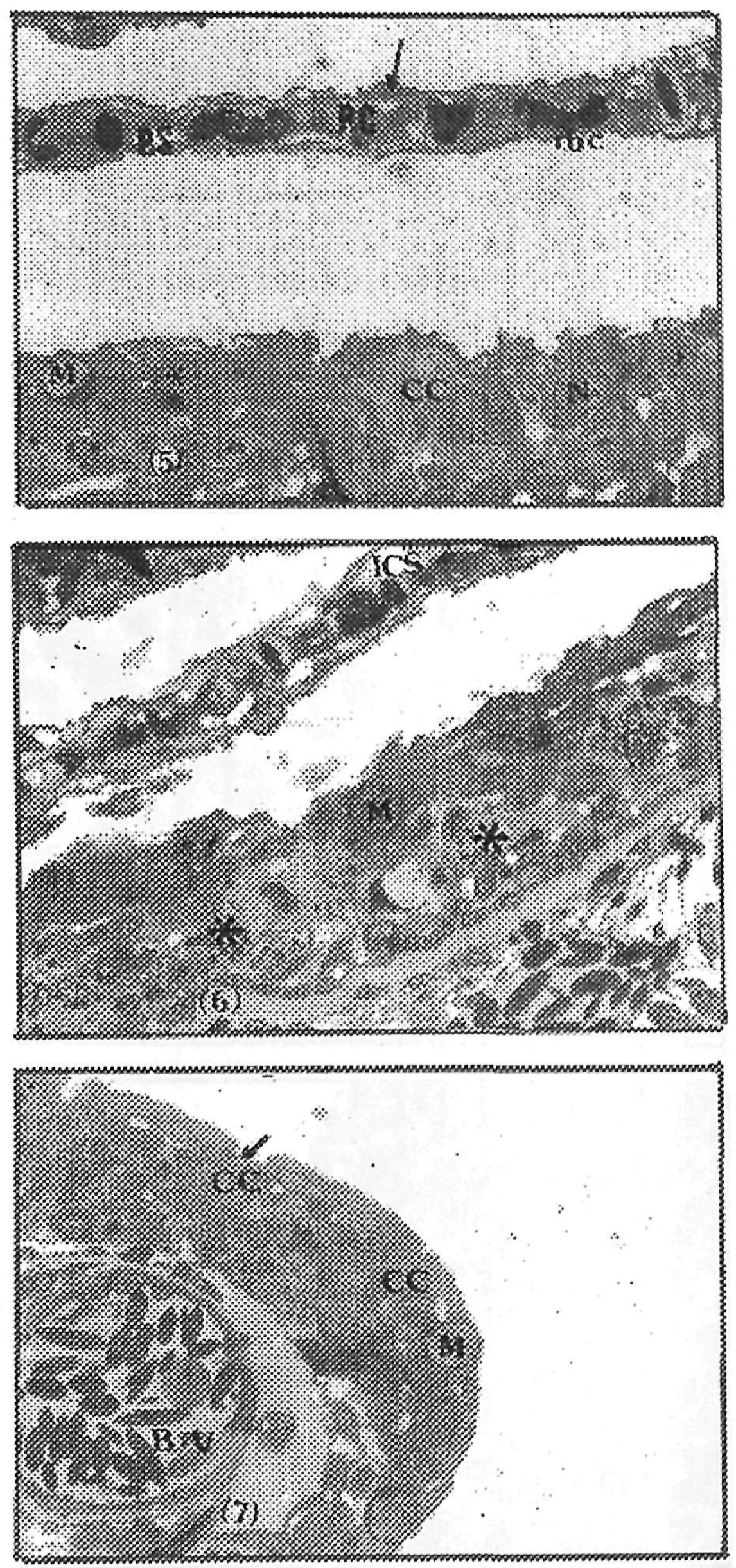

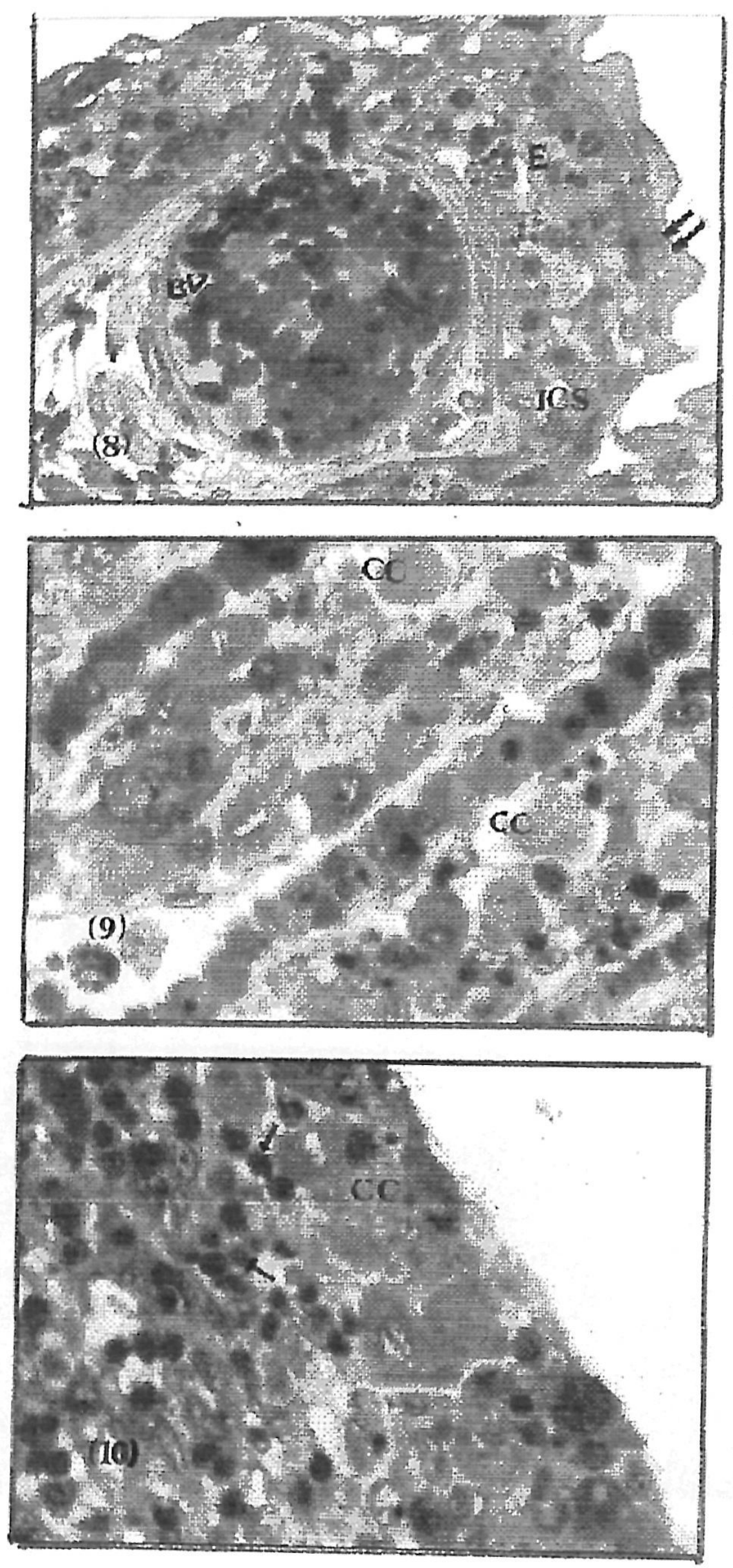

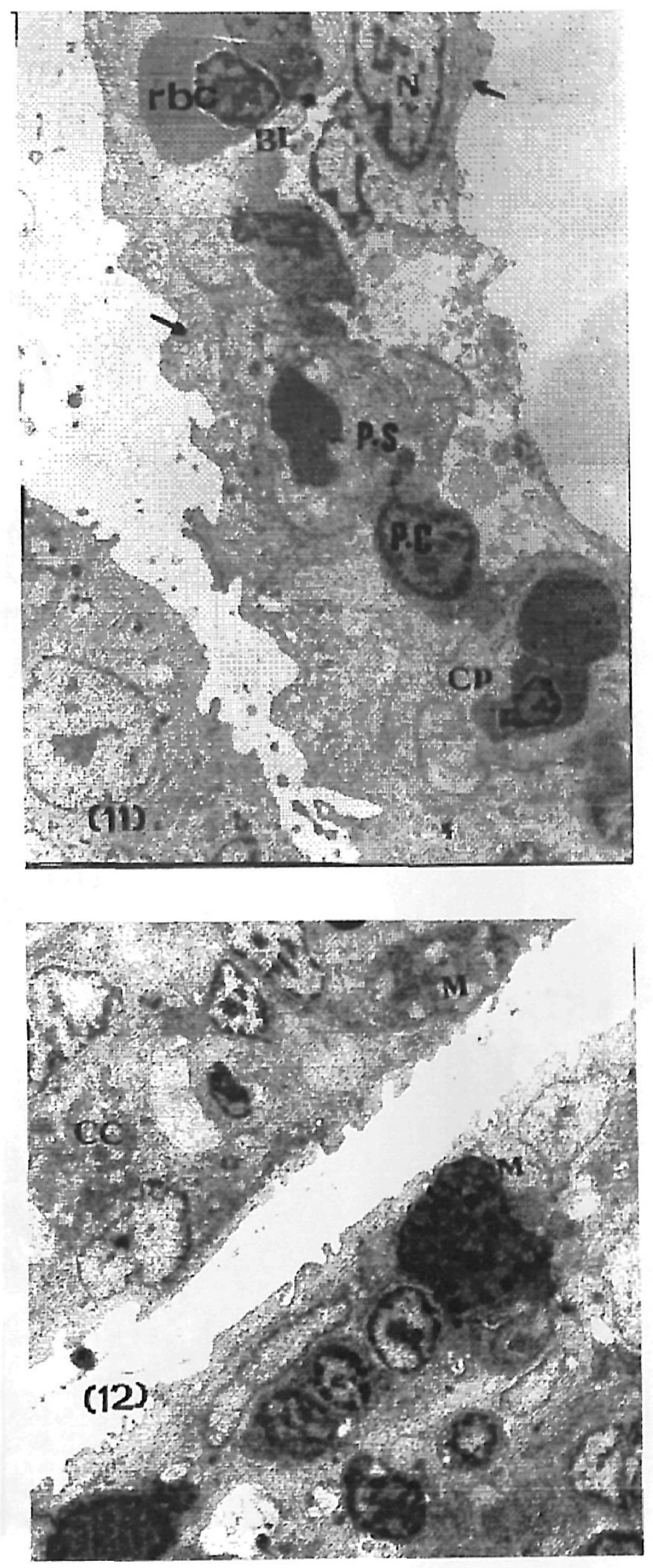


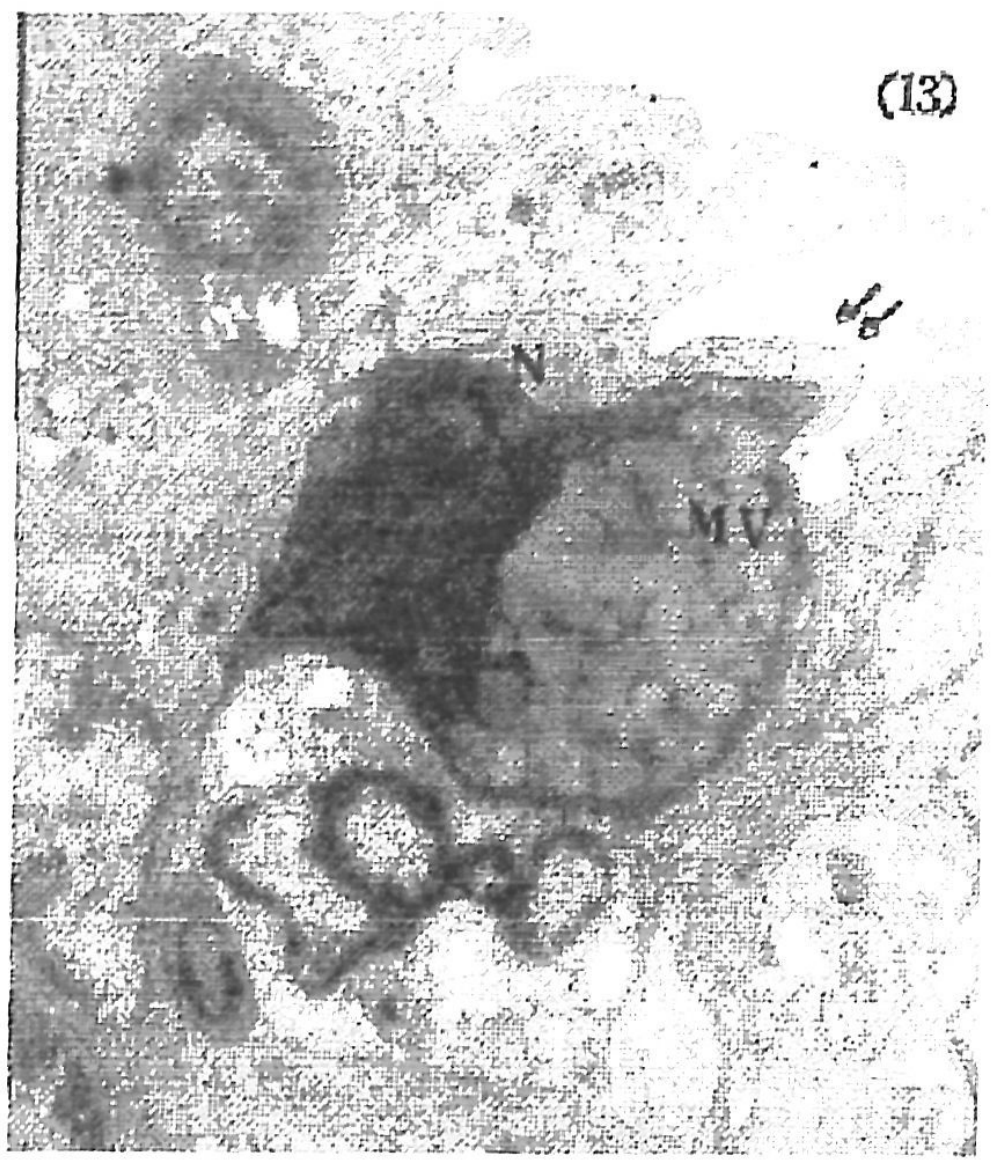

(19)

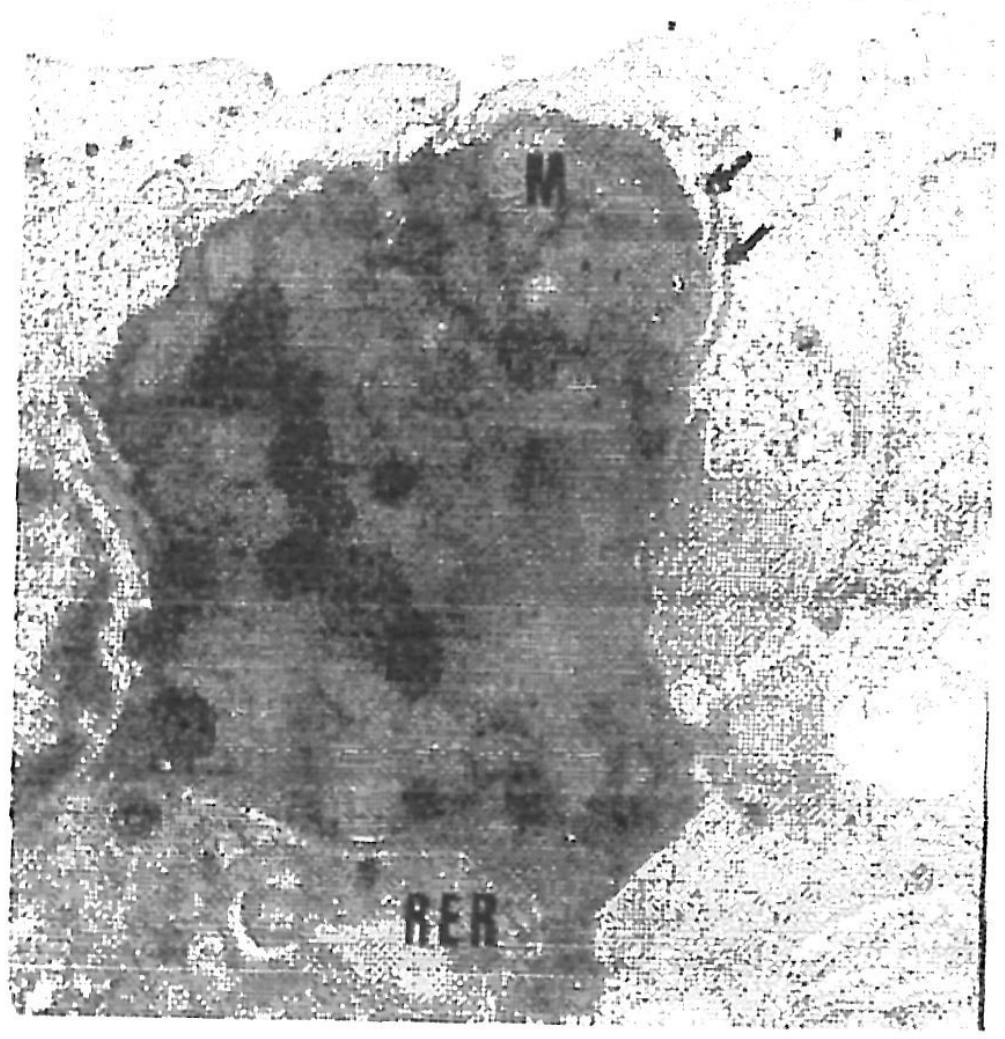



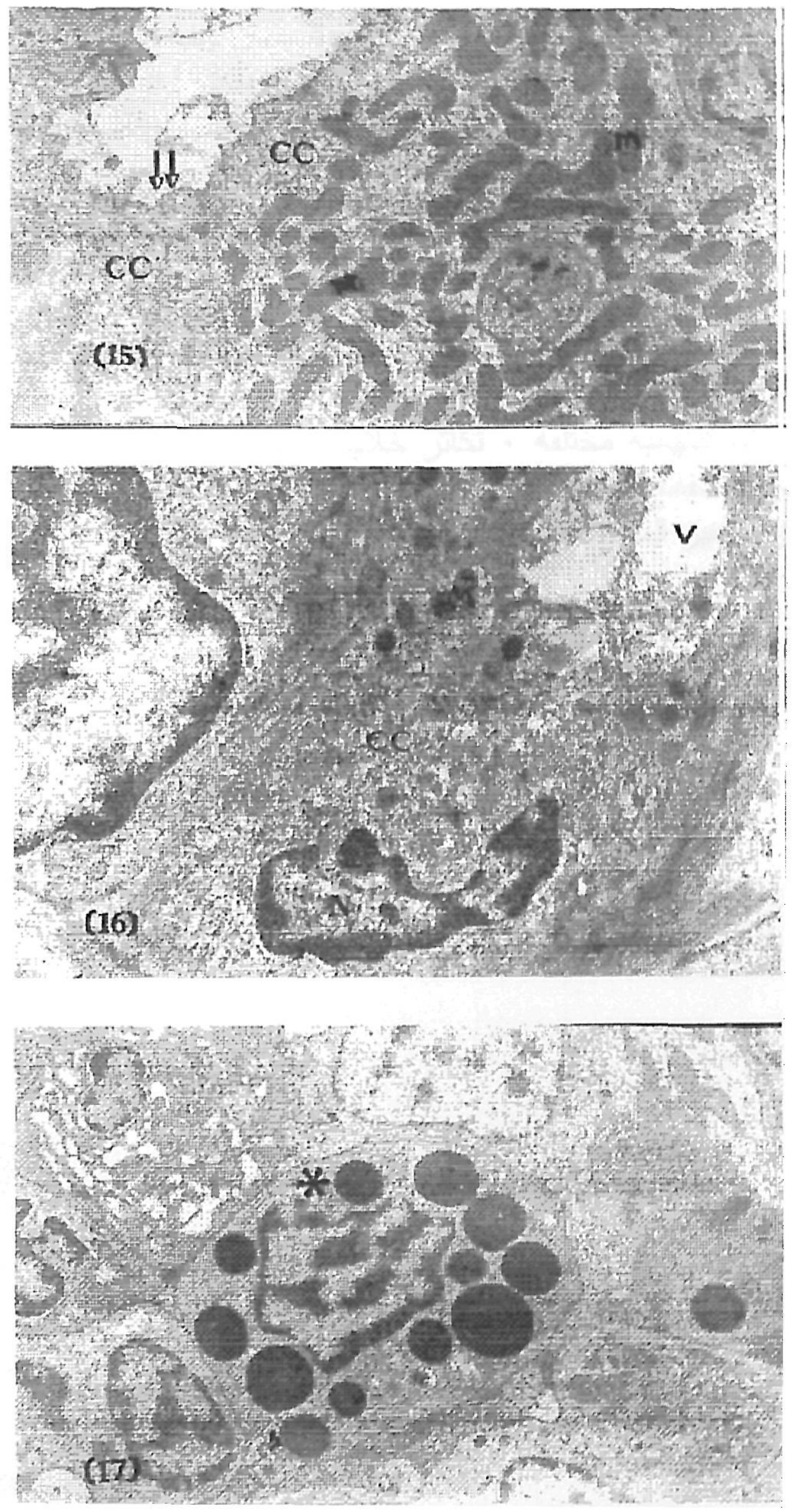